\title{
The Development of Ethnoscience-Based Chemical Enrichment Book as a Science Literacy Source of Students
}

\author{
Mariana Fitriaa,*, Asih Widi Wisudawatia \\ ${ }^{a}$ Department of Chemistry Education, Faculty of Science and Technology UIN Sunan Kalijaga Yogyakarta \\ ${ }^{*}$ Corresponding author: marfifitria@gmail.com
}

\begin{abstract}
This study aims to examine the characteristics and quality of chemical enrichment books based on ethnosciences as a source of science literacy learners. The research method used is Research and Development. Data collection using questionnaire method. Data analysis is done quantitatively and qualitatively. The result of research is in the form of chemical enrichment book based on ethnoscience with characteristics: (1) A5 print media, (2) raised 4 Javanese cultural themes especially Yogyakarta area consisting of Batik, Wayang Kulit, Merapi, and Dagger themes, (3) the theme in general, the transformation of science from indigenous science to scientific science, and the renewal steps that can be made based on the existing environmental or social facts in the theme, (4) developed by containing affective, cognitive, and psychomotor domains. Assessment is performed using an assessment instrument that refers to the instrument B1 of the Center for Curriculum and Bookkeeping. Assessment by material experts, media experts, cultural experts, chemistry teachers, and students' responses were $83.33 \%, 90.9 \%, 60 \%, 84.30 \%$, and $90 \%$, respectively, with Good category (B), Very Good (SB), Enough (C), Very Good (SB), and Good $(B)$, thus this chemical enrichment book deserves to be a source of science literacy by students
\end{abstract}

Keywords: development, enrichment book, ethnoscience, javanese culture, literacy science

\section{INTRODUCTION}

Indonesia is an archipelagic country with multicultural diversity that must be preserved by maintaining the noble values of the Indonesian nation [1]. One effort to preserve multicultural diversity can be done through the education world as it becomes the function and purpose of national education, namely education is a process to develop the potential of students through the transfer of values and local cultural excellence so that students are able to become the heirs and developers of the nation's culture [2].

Education in schools teaches a variety of subjects that fit the applicable curriculum. One such subject is chemistry. Chemical learning aims to gain an understanding of the facts, the ability to solve problems, have the skills in using the laboratory, and able to be scientific in everyday life [3]. In the meantime, in practice chemistry tends to emphasize more on scientific science that makes students less able to view science as a unity that is integrated with environment, technology, and society [4]. In this regard, a study explains that culturally oriented learning is fundamental in education. This culturally oriented learning is called ethnoscience, as explained by Suastra, that ethnoscience is a study of a system of knowledge organized from cultures and events related to the universe contained in society [5]. Chemical learning that links the original science to the culture of society and transformed into scientific science (oriented to the concept of ethnoscience) is assessed to increase students' science literacy [6].

The science literacy analysis that has been done by PISA in 2015 about the value of science literacy of students in Indonesia, shows the average value of students in Indonesia is 403 when compared with the international average of 493, it can be said that the results of science literacy students in Indonesia still far behind. A very low achievement below the international average, according to Toharudin, it can be said that the ability of science of new Indonesian students to recognize a number of basic facts, but has not been able to communicate and link various topics to science, let alone apply complex and abstract concepts. Therefore, it is important for science learning to participate in combining linguistic elements such as aspects of writing, speaking and reading, because this linguistic aspect is the key to scientific literacy [7].

In connection with the above statement, Kemendikbud has created a new program to improve the culture and reading interest called literacy program that has been running since 2015. Based on interviews that researchers have done related to literacy activities, some schools have implemented literacy programs with reading books 15 minutes before the learning process begins. Literacy activities have been implemented since 2015, while the books that students read are non-fiction type books such as novels, short stories and 
some books of general knowledge, while enrichment books that can increase student insight are rarely read given the availability in schools is also still small. Observations that researchers have done in several bookstores in the city of Yogyakarta are related to the availability of enrichment books, that the number of enrichment books is not as much as textbooks, enrichment books that present local cultural richness are also not widely available.

Based on the analysis of the above needs, the researcher wants to develop self-learning resources in the form of chemical enrichment book based on ethnoscience as a source of student science literacy. This enrichment book was developed on the grounds that (1) the need for a learning resource in the form of enrichment books that raised the local culture as a form of love of the nation's culture and then studied from the side of science as a source of students' science literacy, (2) the unavailability of chemical-based enrichment book based on ethnoscience common in the community, so with the enrichment book is expected students can know the application of chemistry in daily life primarily in the culture of society in Indonesia.

\section{LITERATURE REVIEW}

\section{Enrichment Book}

The book of enrichment is a book that contains materials that can enrich and enhance the mastery of science and technology, skills, and shaping the personality of students, educators, educational managers, and other readers. The enrichment books are not for students only [8]. According to Permendiknas No. 2 Year 2008, the enrichment book contains materials that can enrich basic textbooks of education, secondary education, and college.

The enrichment book belongs to a type of non-text book, i.e. books that are not used directly as a source book or as a reference from one particular field of study at an educational institution. Basically in the process of preparing the book of enrichment does not have to be tied to the curriculum directly, but must remain in accordance with the objectives of National education. The enrichment feature traits are as follows [8]:

a. Books that can be used in a school or educational institution but not a compulsory reference book used in the learning process.

b. Books that provide wider material to complement textbooks that contain extensive and in-depth information on science and technology, or can be a handbook.

c. Non-teaching books are not published in series based on grade or level of education.

d. Non-teaching books containing materials that are not directly related to some or one of the Basic Competency Standards or Competencies contained in the Contents, but have a linkage to support the achievement of national education objectives.

e. The material of the non-text book can be read by readers of all levels of education or by the general reader.

f. The presentation of non-text book lessons is loose, creative, and innovative so as not to be bound by the provisions of the process and systematic learning, which is determined based on science and teaching.

\section{Ethnoscience}

Ethnoscience is derived from the word "ethnos" from the Greek meaning the nation and the word "scientia" from Latin meaning knowledge. Ethnoscience is a study of knowledge systems based on culture and events related to the universe found in society [5]. Ethnoscience can also be said to be a set of knowledge gained by a particular method based on tradition or culture in a society whose truth can be expressed scientifically [9]. Hence, ethnoscience-based learning is a science-oriented learning community then explained through scientific science.

There are three topical studies in the study of ethnoscience according to Ahimsa, the first of which is the study of ethnoscience that focuses on culture in terms of environmental classification or social situation. The objective is to know which titles are considered important by the community and to find the principles that people use to understand the symptoms in the environment. Secondly, the study of ethnoscience that focuses on culture in terms of community behavior related to the values and norms prevailing in society, about whether or not something is done. As for the third study of ethnoscience that focuses on culture in terms of the principles of the occurrence of an event in society [10]. 


\section{Scientific Science}

Scientific literacy is defined by PISA as the capacity to perform scientific actions in daily life. These actions range from using scientific knowledge and ability, identifying questions, drawing conclusions based on evidence and data that have been obtained to understand the universe, and making decisions of changes that occur because of human interaction with the universe [11].

The ability of $21^{\text {st }}$ century Scientific literacy to be possessed includes the ability to read, write, calculate, utilize the function of technology, to understand various types of media and information delivery, capable of learning distance learning and E-learning, and also having awareness of the positive impacts negative in terms of the use of modern information and communications technology [12].

\section{METHODS}

The research method applied is Research and Development which is designed to develop self-learning resources in the form of chemical enrichment book based on ethnoscience. The development model used is the Borg and Gall method which is limited to the fifth stage i.e. the initial test revision which includes the following stages [13]:

1. Research and data collection (research and information collecting), consisting of: need assessment which is useful to know the product needed and will be developed, literature study related to product development especially in the form of enrichment book, and ethnoscience concept which will become the characteristics of the enrichment book to be developed, as well as the analysis of materials related to local cultures (Javanese) that can be translated scientifically science with selected materials are batik, wayang kulit, Merapi, and dagger.

2. Planning, Collection of references about batik, wayang kulit, Merapi and dagger, and also the concept of ethnoscience in the culture.

3. Initial development of product draft (develop preliminary form of product) includes the preparation of systematics and components contained in the book enrichment, preparation of the contents of the book and determine the design lay-out or book cover, consult the initial product results with supervisors, product validation, as well as product revisions.

4. Preliminary field testing (preliminary field testing), i.e. by appraisal on 3 chemistry teachers of SMA / MA reviewer, and responded by 10 high school / MA students of IPA program.

5. Revision of the trial results (main product revision). At this stage the product improvement is based on assessment by reviewer and response from high school / MA students.

Data collection method in this research is by using interview and questionnaire method. Interview method is used for requirement analysis in the early stages, and questionnaire method is used to determine the quality of chemical enrichment book. Quality assessment data were collected using research instruments referring to B1 Curriculum and Bookkeeping Center instruments to determine the quality of enrichment books in the form of: (1) Quality Assessment Questionnaire with Likert Scale, (2) Student Response Sheet with ska Gutman. Data analysis for quality data analysis calculation for quality assessment is done based on expert validation and assessment teacher as well as based on student response.

\section{RESULTS AND DISCUSSION}

The importance of Scientific literacy for students to build students' thinking and skills has been supported by a new policy in education, the implementation of literacy programs in schools. This literacy program aims to foster interest and reading culture for students who become one of the efforts to improve Scientific literacy for students in Indonesia who are still far behind other countries based on analysis conducted by PISA (Program for International Student Assessment). However, the availability of learning resources that can help students to improve Scientific literacy has not been widely available in the community. Therefore, the researcher develops chemical enrichment book based on ethnoscience which can be used as a source of Scientific literacy for students so that students not only learn the concept of scientific science only, but also able to explain the concept of indigenous science originating from the culture of local people in Yogyakarta.

Chemical enrichment books developed are A5-sized print media. The material was developed by taking Indonesian resources in accordance with the category of knowledge enrichment books in the B1 Center of Curriculum and Books curriculum which pursued in Javanese culture (Yogyakarta). The material is presented in 4 Javanese cultural themes namely Batik, Wayang Kulit, Merapi, and Dagger. These themes become the main topic for studying the science of society in the area of Yogyakarta. 
The theme of Batik and Wayang Kulit contains information that Javanese culture is rich in high artistic value so that batik and shadow puppets become cultural heritage of archipelago that need to be preserved. The Dagger theme contains cultural information in terms of technology inherent in Javanese society, while the theme of Mount Merapi contains information of natural events contained in the Java community.

As a book that can be a source of Scientific literacy, this enrichment book is developed following the steps in developing the enrichment book. As for the steps are preparing basic concepts of writing, pay attention to the creative process, adjust the ability to think readers, and determine the aspects that will be developed. As in this chemical enrichment book the developed aspects contain cognitive, affective, and psycho-motoric domains [8].

Cognitive domain is manifested through the concept of ethnoscience, that is by translating community science (local knowledge society) to scientific science relevant to the truth of science, so students are invited to think and analyze that a lot of science applications that exist in everyday life. The concept of ethnoscience in the enrichment book is presented in the "What The Science Said?" Column as in Figure 1.

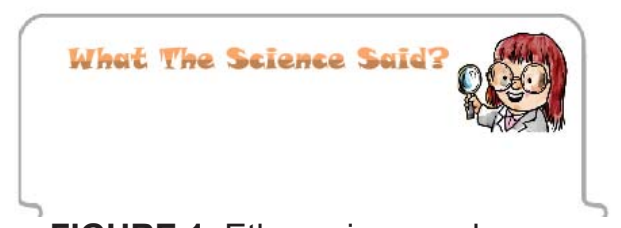

FIGURE 1. Ethnoscience coloumn

In the column, scientific explanations of science that follow the flow of community science in every cultural theme, so that community science is a reference in writing this column of ethnoscience. Study of ethnoscience on batik theme about batik making process, on Wayang Kulit theme about leather drying process and leather puppet making, on the theme of Mount Merapi to review the signs of natural events according to Javanese society, and on the theme of Dagger review the process of making and sharpening. The process of transforming the science of society (indigenous science) to scientific science on each theme can be seen in Table 1.:

TABLE 1. Science Transformation of Batik theme

\begin{tabular}{|c|c|c|c|}
\hline No & Stages & Indigenous Science & Science \\
\hline 1. & Liquid wax & $\begin{array}{l}\text { Liquid waxing is done so } \\
\text { that the wax can be } \\
\text { attached to the fabric }\end{array}$ & $\begin{array}{l}\text { Explanation of changes in the form of objects. } \\
\text { Wax liquefaction is the process of changing the form } \\
\text { of substance from solid to liquid, due to absorption of } \\
\text { heat. the heat absorbed causes the distance } \\
\text { between the wax molecules to be further away, so } \\
\text { that the wax changes shape. }\end{array}$ \\
\hline 2. & $\begin{array}{l}\text { Batik } \\
\text { designing }\end{array}$ & $\begin{array}{l}\text { Sticking the wax on the cloth } \\
\text { is useful to cover the motifs } \\
\text { on batik cloth. }\end{array}$ & $\begin{array}{l}\text { The occurrence of heat absorption process of liquid } \\
\text { wax by fabric fibers and by the environment so that } \\
\text { wax molecules become tight again and its form } \\
\text { becomes solid and become a protective layer for } \\
\text { batik motif. }\end{array}$ \\
\hline 3. & Staining & $\begin{array}{l}\text { Giving dye on cloth to look } \\
\text { more beautiful batik cloth }\end{array}$ & $\begin{array}{l}\text { Explanation of polar and non-polar covalent bonds. } \\
\text { In the staining stage it begins with the dissolution } \\
\text { process i.e. the dissolution of the dyestuff with water } \\
\text { as the solvent which indicates that the dissolution } \\
\text { process can only occur between the solvent and the } \\
\text { solute having the same polarity properties. }\end{array}$ \\
\hline 4. & Threshing & $\begin{array}{l}\text { Removal of wax coating on } \\
\text { fabric is easy using hot } \\
\text { water mix with soda ash or } \\
\text { water glass to make wax } \\
\text { easier to peel. }\end{array}$ & $\begin{array}{l}\text { Soda ashes with chemical names } \mathrm{NaCO}_{3} \text { which is a } \\
\text { weak base will hydrolyze the fat (R-COOH) in the } \\
\text { wax, so that the wax into a soluble soap in water. } \\
\text { The influence of temperature on water also causes } \\
\text { the process of wax removal becomes faster because } \\
\text { the wax absorbs heat from the water so that the wax } \\
\text { will melt. }\end{array}$ \\
\hline
\end{tabular}




\begin{tabular}{cllrl}
\hline 5. Fixation & $\begin{array}{l}\text { Add alum } \\
\text { dyestuffs }\end{array}$ & to prevent & $\begin{array}{l}\text { The addition of } \mathrm{Al}_{2}\left(\mathrm{SO}_{4}\right)_{3} \text { on the dye serves for the } \\
\text { color amplifier. }\end{array}$ \\
\hline
\end{tabular}

TABLE 2. Science Transformation of wayang kulit theme

\begin{tabular}{|c|c|c|c|}
\hline No & Stages & Indigenous Science & Science \\
\hline 1. & $\begin{array}{l}\text { Gamela } \\
\mathrm{n} \\
\text { material } \\
\mathrm{s}\end{array}$ & The gamelan is made of bronze & $\begin{array}{l}\text { Explanation of the chemical elements of the } \\
\text { composition of the gamelan copper (Cu), tin } \\
(\mathrm{Sn}) \text {, and bronze (Alloy Cu and Sn) }\end{array}$ \\
\hline 2. & $\begin{array}{l}\text { Drying } \\
\text { skin }\end{array}$ & $\begin{array}{l}\text { The skin is cleaned and dried to } \\
\text { make skin durable and not } \\
\text { rotten. }\end{array}$ & $\begin{array}{l}\text { Explanation of the skin that the skin as a } \\
\text { protector of the body of living beings. Drying of } \\
\text { the skin is useful for reducing the water } \\
\text { content of the skin to prevent the growth of } \\
\text { bacteria that cause damage to the skin. }\end{array}$ \\
\hline 3. & Staining & $\begin{array}{l}\text { Coloring on finished leather } \\
\text { using paint aims to embellish } \\
\text { puppet characters and more } \\
\text { durable }\end{array}$ & $\begin{array}{l}\text { The explanation of colloids, where the paint } \\
\text { used in the staining process is one example of } \\
\text { colloids. } \\
\text { Paint is used to provide a layer on the skin so } \\
\text { that the skin surface is not easy to interact with } \\
\text { water or moist air so the skin does not quickly } \\
\text { damage. }\end{array}$ \\
\hline 4. & Stalking & $\begin{array}{l}\text { The stalk is installed for easy } \\
\text { play when a puppet show is in } \\
\text { progress. }\end{array}$ & $\begin{array}{l}\text { The stalk is where the resultant gravity is } \\
\text { applied to the object. }\end{array}$ \\
\hline
\end{tabular}

TABLE 3. Science Transformation of Mount Merapi theme

\begin{tabular}{|c|c|c|c|}
\hline No & Stages & Indigenous Science & Science \\
\hline 1. & $\begin{array}{l}\text { Local view of } \\
\text { the eruption of } \\
\text { Merapi }\end{array}$ & $\begin{array}{l}\text { Locals say that when } \\
\text { eruption means "Merapi } \\
\text { nembe gadhah damel" } \\
\text { which means Merapi is } \\
\text { having a celebration. } \\
\text { They also assume that } \\
\text { not all eruptions will } \\
\text { cause disasters, } \\
\text { because they have } \\
\text { analyzed the risks and } \\
\text { benefits that occur after } \\
\text { the eruption. }\end{array}$ & $\begin{array}{l}\text { The eruption occurs when the magma has } \\
\text { come out to the surface of the earth. Along with } \\
\text { the magma that comes out, a lot of earth } \\
\text { material that comes along, thus providing many } \\
\text { benefits for local residents such as for building } \\
\text { materials if the materials are large, and mineral } \\
\text { content rich in nutrients can fertilize the soil, } \\
\text { after the eruption occurs. }\end{array}$ \\
\hline 2. & $\begin{array}{l}\text { Prediction of } \\
\text { Eruption }\end{array}$ & $\begin{array}{l}\text { Locals use the science of } \\
\text { "titen" that is } \\
\text { remembering and } \\
\text { recognizing the natural } \\
\text { signs that occurred } \\
\text { before the eruption. For } \\
\text { example, wilted plants } \\
\text { and forest animals begin } \\
\text { to descend from the } \\
\text { mountains. }\end{array}$ & $\begin{array}{l}\text { The wilted plant is caused by the rising } \\
\text { temperature of the environment, and the drying } \\
\text { of the water source due to magma activity so } \\
\text { that the plants become withered. Animals will } \\
\text { also migrate to safer places because they feel } \\
\text { disturbed by the roar and rising temperatures. }\end{array}$ \\
\hline 3. & $\begin{array}{l}\text { Danger sign } \\
\text { with } \\
\text { kentongan }\end{array}$ & $\begin{array}{l}\text { Kentongan is used to } \\
\text { give a danger sign by } \\
\text { being hit with a fast } \\
\text { tempo }\end{array}$ & $\begin{array}{l}\text { Explanation of sound waves and mechanisms } \\
\text { of hearing in the human ear. }\end{array}$ \\
\hline
\end{tabular}


TABLE 4. Science Transformation of Dagger theme

\begin{tabular}{|c|c|c|c|}
\hline No & Stages & Indigenous Science & Science \\
\hline 1. & Forging & $\begin{array}{l}\text { Liquid ore melting and mixed } \\
\text { metals, then printed on a metal } \\
\text { mold to form metal bars. }\end{array}$ & $\begin{array}{l}\text { Forging is a process of forming metals by } \\
\text { means of sufficient heating so that the } \\
\text { metal becomes plastic and then given } \\
\text { pressure or blow to the mold }\end{array}$ \\
\hline 2. & Gilding & $\begin{array}{l}\text { The iron is heated until } \\
\text { smoldering is subsequently } \\
\text { inserted in cold water. }\end{array}$ & $\begin{array}{l}\text { Gilding is referred to as quenching that is } \\
\text { giving of heat to the metal so that the } \\
\text { metal is warming slowly and followed by } \\
\text { rapid cooling using water for martensitic } \\
\text { structure. }\end{array}$ \\
\hline 3. & $\begin{array}{l}\text { Cleansing of } \\
\text { dagger }\end{array}$ & $\begin{array}{l}\text { Dagger soaked with young } \\
\text { coconut water, then soaked in } \\
\text { warangan liquid and added with } \\
\text { lime juice }\end{array}$ & $\begin{array}{l}\text { Young coconut water is acidic weak so it } \\
\text { can help to remove rust The liquid is a } \\
\text { mixture of arsenic }\left(\mathrm{AS}_{2} \mathrm{O}_{3}\right) \text {, lime liquid } \\
\left(\mathrm{C}_{3} \mathrm{H}_{4} \mathrm{OH}\right) \text { and iron filings. This fluid that } \\
\text { serves as a thin layer forming to protect } \\
\text { from the coronation of arsenic iron oxide } \\
\text { compounds }\end{array}$ \\
\hline 4. & $\begin{array}{l}\text { Making of } \\
\text { warangka }\end{array}$ & $\begin{array}{l}\text { Maintenance the dagger's } \\
\text { sharpening }\end{array}$ & $\begin{array}{l}\text { Protection from direct contact of dagger } \\
\text { with moist air or water as an initiator of the } \\
\text { occurrence of corrosion. }\end{array}$ \\
\hline 5. & $\begin{array}{l}\text { Protection with } \\
\text { oil (jafaron, } \\
\text { misik) }\end{array}$ & $\begin{array}{l}\text { Giving offerings to the dagger } \\
\text { that is believed to give power to } \\
\text { the owner }\end{array}$ & $\begin{array}{l}\text { Explanation of corrosion. } \\
\text { Oil viscosity can prevent contact between } \\
\text { iron and air and water. The oil differs from } \\
\text { its polarity to the water so that the } \\
\text { perfume prevents the contact between } \\
\text { dagger and water or moisture. }\end{array}$ \\
\hline 6. & $\begin{array}{l}\text { Cleansing with } \\
\text { lemon }\end{array}$ & To clean the rust on the dagger & $\begin{array}{l}\text { Citric acid content in lime will react with } \\
\text { rust of iron so that the rust of iron will be } \\
\text { eroded. } \\
\text { Explanation related to acid-base theory }\end{array}$ \\
\hline 7. & $\begin{array}{l}\text { Provision of } \\
\text { coconut oil } \\
\text { during the } \\
\text { scouting }\end{array}$ & For the protection of dagger & $\begin{array}{l}\text { The nonpolar group of oils serves to } \\
\text { protect the iron from different water } \\
\text { polarity, preventing the occurrence of } \\
\text { corrosion. }\end{array}$ \\
\hline
\end{tabular}

The affective domain in this enrichment book is manifested through the presentation of one of the puppet characters in the Wayang Kulit theme, Arjuna. Arjuna described as a knight figure who likes to study, studied, and meditated. The characters can be used as an example by students to always be passionate in studying, as well as being polite to the teacher. In addition students are also expected to imitate the arjuna characters who like to meditate, with a slight shift of meaning which means able to refrain from excessive worldly desires, let alone spree and lazing.

Psychomotor domains appear slightly different from other books. In this book, the psychomotor domain is not manifested by physical activity, but rather the invitation to act to be better after exposure to environmental symptoms and social phenomena present in society. For example on the theme Batik, the author invites readers to use batik dyes that come from plants to be more environmentally friendly. In the theme of Mount Merapi, the authors explain that the existence of magma as geothermal source, has the potential to be a Geothermal Power Plant (PLTP) so it is not necessary to spend a lot of fuel as a source of combustion for power plants.

The enrichment book also comes with a "Tell You" column that explains interesting info related to the theme, as can be seen in Figure 2. 


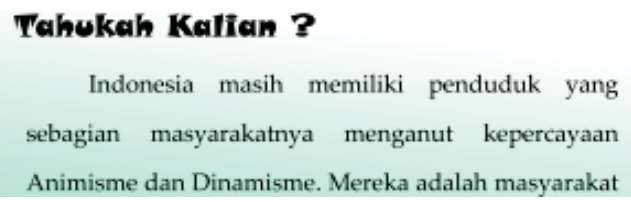

FIGURE 2. Information column

In batik theme, the information column explains the concept of batik by way of providing a waxy coating on the fabric which becomes a barrier of the dye, the same as the taro leaves coated by a candle and not wet when exposed to water. In the theme of wayang kulit, the information column explains the animism and dynamism beliefs that still exist in Indonesia, from that belief the beginning of the wayang. Then on the theme of Mount Merapi this column describes the compounds contained in the magma during the eruption of Merapi and explanation of different hemoglobin content in people living in the highlands with people living in the lowlands.

Chemical enrichment books based on ethnoscience developed have characteristics that support the goal of national education is to develop students' potential by developing science, skills, and creativity for students through the material presented. The results of the quality assessment by the lecturers of material experts, media experts, cultural experts, chemistry teachers and student responses covering aspects of content / material feasibility, ethnoscience aspects, presentation aspects, and linguistic aspects and graphics with instruments referring to the instrument B1 Central Curriculum and Book can be seen in Table 5.

TABLE 5. Quality of Chemical Enrichment Books by Material Experts, Media Experts, Cultural Experts, and Cultural Experts

\begin{tabular}{ccccc}
\hline Aspect & $\begin{array}{c}\text { Material } \\
\text { Experts }\end{array}$ & $\begin{array}{c}\text { Media } \\
\text { Experts }\end{array}$ & $\begin{array}{c}\text { Cultural } \\
\text { Experts }\end{array}$ & Cultural Experts \\
\hline Feasibility of Content & 13 & & & 12.33 \\
Ethnoscience & 12 & - & - & 13.33 \\
Presentation & - & 12 & - & 12.67 \\
Language and Graphic & - & 38 & - & 33.33 \\
Percentage \% & 83.33 & 90.90 & 60.00 & 84.30 \\
Category & B & SB & C & SB \\
\hline
\end{tabular}

The results of data analysis in Table 1, it can be seen that the acquisition of scores from material experts obtain good categories, scores from media experts get very good category, cultural expert get category score enough, and score from teacher get very good category. The initial test phase is done after the product is validated and assessed by the experts then responded to the students. Response data by 10 students can be seen in Table 6.

TABLE 6. Quality of Chemical Enrichment Books by Student Response

\begin{tabular}{ccccc}
\hline Aspect & $\begin{array}{c}\sum \text { Score Per } \\
\text { Aspect }\end{array}$ & $\begin{array}{c}\sum \text { maximum } \\
\text { score }\end{array}$ & Percentage (\%) & Category \\
\hline Material Feasibility & 4.8 & 5 & 96.00 & $\mathrm{~B}$ \\
Content & 4.5 & 5 & 90.00 & $\mathrm{~B}$ \\
Ethnoscience & $\begin{array}{c}\text { Score Per } \\
\text { Aspect }\end{array}$ & $\begin{array}{c}\text { maximum } \\
\text { score }\end{array}$ & Percentage (\%) & Category \\
Aspect & 2.9 & 3 & 97.00 & $\mathrm{~B}$ \\
Presentation & 5.8 & 7 & 82.00 & $\mathrm{~B}$ \\
Language and graphics & 18.0 & 20 & $90 / 00$ & $\mathrm{~B}$ \\
\hline Total & & & & \\
\hline
\end{tabular}

The results of the assessment analysis based on student responses can be seen that each aspect gets a good category, so it can be concluded that this enrichment book is easy to understand and get good response from students. 


\section{CONCLUSION}

Based on the results of data and research, can be taken some conclusions that is the character of enrichment-based chemical book product ethnoscience is an A5-sized print media. The enrichment book raises 4 Javanese cultural themes especially Yogyakarta area consisting of Batik, Wayang Kulit, Merapi, and dagger themes. Each theme consists of three parts: the theme information in general, the transformation of science from indigenous science to scientific science, and the renewal steps that can be made based on the environmental or social facts present in the theme. Enrichment books are developed by loading affective, cognitive, and psychomotor domains. The result of the assessment of the book enrichment by the expert gets the value of achievement with the category of minimal enough and maximal very good and get good response from the students, so this chemical enrichment book can be said as feasible as the source of student's literacy.

\section{REFERENCES}

1. Depdiknas, Model Mata Pelajaran Muatan Lokal (Depdiknas, Jakarta, 2006).

2. Kementrian Pendidikan dan Kebudayaan, Dokumen Kurikulum 2013 (Kemendikbud, Jakarta, 2012).

3. T. Sastrawijaya, "Proses Belajar Mengajar Kimia" (P2LPTK Dirgen Dikti Depdikbud, Jakarta, 1988).

4. D. Nugraheni, S. Mulyani and S. R. D. Ariani, JPK, 3, 2, 34 - 41, 2013.

5. I. W. Suastra, JPP IKIP Negeri Singaraja, 3, 1, 377 - 396, 2005.

6. A. Nisa', Sudarmin and Samini, USEJ, 4, 3, 1049-1056, 2015.

7. U. Toharudin, S. Hendrawati, H. A. Rustaman, (Humaniora, Bandung, 2011).

8. Pusat Kurikulum dan Perbukuan. Pedoman Penulisan Buku Nonteks Pelajaran (Departemen Pendidikan Nasional, Jakarta, 2008).

9. E. Matanga, and S. Jerie, JSDA, 13, 4, $369-409,2011$.

10.H. S. A. Putra, "Ethnoscience dan Etnoteknologi", (Kongres Kebudayaan, Bukittinggi, 2003).

11.PISA 2012 Results: Ready to Learn (Volume III) Student's Engagement, Drive and Self Beliefs (OECD Publishing, 2013).

12.S. Nasution, "Berbagai Pendekatan dalam Proses Belajar Mengajar" (PT Bumi Aksara, Jakarta, 2008).

13.N. S. Sukmadinata, Metode Penelitian Pengembangan, (PT Remaja Rosdakarya, Bandung, 2011). 